\title{
Environmental Learning Workshop: Lichen as Biological Indicator of Air Quality and Impact on Secondary Students' Performance
}

\author{
Mohd Wahid Samsudin ${ }^{1}$, Rusli Daik ${ }^{1}$, Azlan Abas ${ }^{2}$, T. Subahan Mohd Meerah ${ }^{3} \&$ Lilia Halim ${ }^{3}$ \\ ${ }^{1}$ School of Chemical Sciences and Food Technology, Universiti Kebangsaan Malaysia, Selangor, Malaysia \\ ${ }^{2}$ Faculty of Social Science and Humanities, Universiti Kebangsaan Malaysia, Selangor, Malaysia \\ ${ }^{3}$ Faculty of Education, Universiti Kebangsaan Malaysia, Selangor, Malaysia \\ Correspondence: Mohd Wahid Samsudin, School of Chemical Sciences and Food Technology, Universiti \\ Kebangsaan Malaysia, 43600 UKM Bangi, Selangor, Malaysia. Tel: 60-389-215-449. E-mail: wahid@ukm.my
}

\author{
Received: February 7, 2013 Accepted: April 7, 2012 Online Published: May 13, 2013 \\ doi:10.5539/ies.v6n6p28 URL: http://dx.doi.org/10.5539/ies.v6n6p28
}

\begin{abstract}
In this study, the learning of science outside the classroom is believe to be an added value to science learning as well as it offers students to interact with the environment. This study presents data obtained from two days' workshop on Lichen as Biological Indicator for Air Quality. The aim of the workshop is for the students to gain an understanding on various aspects on Lichens and its role as a biological indicator. Students are exposed to the following concepts and skills in the workshop: characteristics of algae, the concept of Lichen, causes of polluted air, the concept of quadrant, how to measure the frequency of Lichen, types of Lichen, determining the air quality index, factors determining the quality of air, the role of Lichen, the function of Lichen as a biological indicator and determining the level of air pollution. Four schools participated in the two day workshop whereby two schools were located in rural and urban areas respectively. A total of 125 students were given a pre-test on the concept of Lichen before the workshop followed by brief lecture sessions, hands-on and field work activities, presentation by students. At the end of the workshop, students were given a post-test. Overall, from the pre and post-test results, there is a significant difference in terms of students' performance from all the four schools, in knowledge and skills relating to Lichen and its role as a biological indicator in determining the quality of air.
\end{abstract}

Keywords: environmental learning, lichen, air quality, secondary students, biological indicator

\section{Introduction}

The World's Earth Day which was introduced in 1970 is the beginning of the era of environment. Environmental problems experienced by today's society could be overcome through changes in personel behaviour (Gigliotti, 1992). The environmental problem faced now is not limited to a particular country but it is also a global issue. Thus, it is necessary to create awareness of environmental problems and issues for the masses. Education plays an important role in providing and creating awareness about environment and the problems associated with it. Awareness of environmental issues is seen as a catalyst to behavioural change towards environment. The main aim of environmental education at school is to create awareness among students about and on environment and the problems as well as inculcation of positive attitudes towards environment. This is to ensure that the students are able to play a more effective role in managing the environment. Thus, it is necessary to understand to what extent students are aware of their environment, environmental problems and species that are available in their environment.

In Malaysia, environmental education is implemented across the curriculum. The approach 'across curriculum' refers to the integration of content and skills relating to environment in an existing subject content without jeopardizing the integrity of the existing subject or giving a negatif impact to a particular subject (Hungerford et al. 1994). Even though, Nillson (2008) suggests that this approach has advantages in terms of giving autonomy to the teachers in deciding whether the learning of environment should be done on its own or integrated at the end of each lesson, but due to the lack of time and also the already heavy loaded curriculum, such integration might not occur. It is due to this reason that the inculcation of knowledge, attitude, and behaviour towards the environment is often at low and moderate level (Norlila, 2007; Mageswary et al., 2006).

Based on the curriculum analysis of environmental education documented in 'Teachers Guide on Environmental 
Education Across KBSM Curriculum' (Sharifah, 2011), it was found that the aim of environmental education was inculcated holistically across the curriculum. The inculcation includes all aspects related to environmental education namely knowledge, awareness, attitude, behaviour and actions towards environment. However, the analysis found that environmental issues appear repeatedly across content leading to redundancy. In addition, the relevancy of the content to environmental issues is unclear resulting difficulties in implementing the suggested activities in the curriculum especially when the activities are expected to be conducted outside the classroom.

This article discusses on the learning outcome about science and environment in which environment was used as a learning space and the learning experiences were implemented through an educational program or workshop. The focus of the learning experience is on knowing Lichen and it is conducted using learning and teaching module. Lichen is an interaction of at least two micro- organisms that are from various species of algae, bacteria and fungus. Lichen can also use as biological indicator to determine the air quality of a location. An evaluation of the feasibility of this educational program or workshop in developing knowledge of Lichen and its role in determining air quality among secondary students is also conducted in this study. Thus the research questions of the study are the following:

i. Are there any changes in the level of students' knowledge of Lichen before and after the workshop that uses the learning and teaching module on Lichen?

ii. Are there any differences in performances among the four selected schools on students' understanding of the relationship between Lichen and the level of air pollution?

iii. Are there any differences in performances on the pre and post-test results based on gender?

iv. Are there any differences in the students' performances based on the types of questions on Lichen?

\section{Methodology}

This research employed the action research approach in which learning and teaching module on Lichen is the main instrument. A learning and teaching module on the role of Lichen as a biological indicator in identifying the state of air pollution was used with the workshop participants. The module was adapted and improved from the one that was used in the previous program (Mohd Wahid Samsudin et al., 2011a; Mohd Wahid Samsudin et al., 2011b). The current module emphasised on using the environment as a science laboratory.

Another feature of the module used in the current study that is different from the previous modules is that students are being exposed to how Lichen is used as a biological indicator as a means to monitor the quality of air. The previous modules focussed more on using the environment as a learning space to know the diverse species and interactions between the species. In addition, the learning activities in the module are also multidisciplinary. Students draw on the other disciplines of science such as chemistry (the use of chemical solution in the experiment), biology and ecology (lichen is the interaction among algae, bacteria and fungus) and mathematics (data analysis) in executing the activities. Disciplines from the humanities are also integrated in the learning activities.

Students are also encouraged to draw on their knowledge in geography and introduced to latest technology in the field of geography (mapping; Global Positioning System (GPS); Geographic Information System, GIS), civics (decision making and actions related to environment) and arts (photography and drawing). The two day workshop involves lectures and hands on activities. The lecture was to introduce to the students on lichen and how to use lichen to measure the quality of air. Thus, the topics were 1) introduction to lichen, 2) identifying lichens, 3) calculating the lichen population, 4) calculating the quality index of air, 5) identifying the level of air quality, 6) comparing the air quality of various locations, and 7) mapping out the various air qualities. The hands on activities were series of experiments relating to the above topics and the activities were carried out in groups of five to six students per group under the guidance of trained facilitators which were graduate students. At the end of the activities, each group was asked to present and display their findings to other groups.

A pre and post-test questionnaire was developed to measure students' knowledge and understanding of the concept of lichen and its role in measuring air quality. The post- test questionnaire was to seek if there was a change in the understanding as a result of participating in the workshop. Both questionnaires consist of 10 items with multiple choice answers. The questions were on the concept lichen and skills in determining the quality of air using Lcihens i.e. characteristics of algae, the meaning of lichen, causes of air pollution, the quadratic concept, the function of lichen as a biological indicator, types of lichen, how to calculate the frequency of lichen, how to identify the index value of air quality, factors in identifying the air quality, role of lichen and the identification of level of air pollution.

The total number of sample was 125 Form Four science students from four secondary schools. A total of 30-34 
students were selected by the teachers from each of the four schools to be involved as program or workshop participants. The four schools were SMK Seri Tangkak ( Johor ),SMK Jeli (Kelantan), SMK Kota Puteri, Pasir Gudang (Johor) dan SMK Kinarut ( Sabah ).

Descriptive analysis was used to describe the students' performances and paired sample t-test was used to analyse for any mean differences. Non-participant observation on the learning environment experienced by the students throughout the workshop was conducted and background information of the schools was collected.

\section{Findings and Discussion}

Table 1 presents the distribution of the test score of students from four schools before and after they were exposed to the learning and teaching module on Lichen. Each student's pre and post test scores are tabled out according to their respective schools.

Table 1. Distribution of the pre and post test scores according to schools

\begin{tabular}{|c|c|c|c|c|}
\hline \multirow[t]{2}{*}{ DISTRIBUTION } & \multicolumn{4}{|c|}{ SCHOOL NAME } \\
\hline & SMK Jeli & SMK Sri Tangkak & SMK Kota Puteri & SMK Kinarut \\
\hline \multirow[t]{7}{*}{ Pre test } & 22302 & 46446 & 22331 & 46446 \\
\hline & 43443 & 25351 & 42224 & 25351 \\
\hline & 10044 & 25262 & 26223 & 25262 \\
\hline & 35654 & 45362 & 32335 & 45362 \\
\hline & 34544 & 42163 & 14323 & 42163 \\
\hline & 42432 & 31313 & 64322 & 31313 \\
\hline & 4 & & & 4432 \\
\hline \multirow[t]{7}{*}{ Post test } & 43344 & 67786 & 89999 & 67786 \\
\hline & 58555 & 77588 & 89878 & 77688 \\
\hline & 53556 & 67777 & 88686 & 67777 \\
\hline & 56755 & 76788 & 67867 & 76788 \\
\hline & 55776 & 866108 & 87776 & 866108 \\
\hline & 64552 & 76577 & 98677 & 76677 \\
\hline & 4 & & & 7764 \\
\hline
\end{tabular}

\subsection{SMK Jeli}

Table 1 shows the pre and post test results for students from SKJ Jeli. The total marks for each test is 10 . The lowest score from the pre-test is 0 while the highest value is 6 . For the post-test the lowest mark was 2 while the highest mark was 8 . About 87.67 per cent of the students showed an increased score from pre to post-test. Only 12.33 per cent of the students obtained similar scores in both the pre and post-tests.

Table 2. Paired sample t test analysis for SMK Jeli

\begin{tabular}{llllllll}
\hline & \multicolumn{2}{l}{ Paired Differences } & & df & Sig.(2-tailed) \\
\cline { 2 - 6 } & $\mathbf{N}$ & $\begin{array}{l}\text { Mean Pre-test \& } \\
\text { Standard Deviation } \\
\text { (SD) }\end{array}$ & $\begin{array}{l}\text { Mean Post-test \& } \\
\text { Standard Deviation } \\
\text { (SP) }\end{array}$ & & \\
\hline Score & 30 & $3.16(1.51)$ & $4.97(1.30)$ & -7.58 & 30 & .000 \\
\hline
\end{tabular}

Table 2 presents the mean score for pre and post-tests for students from SMK Jeli. The pre $($ mean $=3.16)$ and post- tests $($ mean $=4.97)$ mean scores respectively are below the middle value of total score $($ mean $=5)$, which indicates that students' knowledge of Lichen is low before and after the workshop with a mean difference of 1.81 . 
Nevertheless, the mean differences was significant at $0.05(\mathrm{p}=0.000)$. The large value of standard deviation for pre-test $(\mathrm{SD}=1.51)$ and for post-test $(\mathrm{SD}=1.30)$ scores suggests that the ability of the students varied widely with the range of 0-6 marks for pre-test and with a similar range of 2-8 marks for post-test.

The potential of these students to improve their understanding of Lichen, however, is evident in the increased of score means in the post-test, even though the increased mean value is small (1.81). These students are mostly from families who are from the low income range of less than RM1500, and the job occupation are often as farmers, labourers and others. Thus, providing means for their children to attend tuition classes is low. But, it appears that hands-on activities like in the module could probably encourage science learning as evident in the mean differences which is also found to be statistically significant.

\subsection{SMK Sri Tangkak}

Students from SMK Sri Tangkak showed a distribution of 1-8 marks in the pre-test while a range of 4-10 marks in the post-test result (see Table 1). About 96.67 per cent of the students showed an increase in marks from pre to post-test. Only 3.33 per cent achieved the same score in both the pre and post-test score.

Table 3. Paired t-test analysis for SMK Sri Tangkak

\begin{tabular}{lllllll}
\hline & \multicolumn{2}{l}{ Mean differences } & t & df & Sig.(2-tailed) \\
\cline { 2 - 6 } & $\mathbf{N}$ & $\begin{array}{l}\text { Mean Pre-test \& } \\
\text { Standard Deviation } \\
\text { (SD) }\end{array}$ & $\begin{array}{l}\text { Mean test Post \& } \\
\text { Standard Deviation } \\
\text { (SD) - }\end{array}$ & & & \\
\hline Score & 30 & $4.17(1.42)$ & $7.37(1.43)$ & -9.39 & 29 & .000 \\
\hline
\end{tabular}

Table 3 presents the mean scores for both the pre and post-tests of SMK Sri Tangkak students. The mean difference between the pre $(m e a n=4.17)$ and post-test $(m e a n=7.37)$ mean scores is 3.30 and the difference is found to be significant at $0.05(\mathrm{p}=0.000)$. The standard deviation value for the pre $(\mathrm{SD}=1.41)$ and post-test $(\mathrm{SD}=$ $1.43)$ is high respectively. This is evident in the score range for pre-test (1-6 marks) and for post-test (4-10 marks). The relatively high score of pre and post-test, which is close and above the mid value which is 5 indicates the learning process at SMK Sri Tangkak is favourable and encourage learning. Students are mostly from a middle class background where their parents are working with the government with an income between RM2000- RM3000. One can assume that parents might provide basic support in enhancing their children's learning.

In addition, it has been observed that the school learning environment encourages lively interaction among students and races. The location of the school that is closed to a small town next to a Matriculation college possibly induces a high level of motivation of the students to perform in their studies. One can also assume that the activities of the Lichen module encourage the differences in the level of students' knowledge of Lichen.

\subsection{SMK Kota Puteri}

Table 1 shows that the range score for the pre-test results is between 1-6 marks while the range for the post-test results is 6-9 marks. In addition, 100 per cent of the respondents showed an improvement of scores from pre to post-test.

Table 4 shows that the mean score for the pre and post-test $2.87(\mathrm{SD}=1.25)$ and $7.53(\mathrm{SD}=1.04)$ respectively. It appears that the pre-test result indicates a high variability of students' performance while the performance of the students is less variable in the post-test scores. The paired $t$ test also indicates that the differences in mean which is 4.66 is statistically significant at $0.05(\mathrm{p}=0.000)$.

Table 4. Paired sample t-test analysis for SMK Kota Puteri

\begin{tabular}{|c|c|c|c|c|c|c|c|}
\hline & \multicolumn{4}{|c|}{ Mean differences } & \multirow[t]{3}{*}{$\mathbf{t}$} & \multirow[t]{3}{*}{ df } & \multirow{3}{*}{$\begin{array}{l}\text { Sig. } \\
\text { (2-tailed) }\end{array}$} \\
\hline & $\mathbf{N}$ & Mean $\quad$ F & -test \& & Mean Post-test \& & & & \\
\hline & & $\begin{array}{l}\text { Standard } \\
\text { (SD) }\end{array}$ & Deviation & $\begin{array}{l}\text { Standard Deviation } \\
\text { (SD) }\end{array}$ & & & \\
\hline Scores & 31 & $2.87(1.25)$ & & $7.53(1.04)$ & -15.93 & 29 & .000 \\
\hline
\end{tabular}


It appears that students have gained significant improvement in the knowledge of Lichen based on the Lichen module. The hands-on activities in the module might have encouraged such an improvement. In addition SMK Kota Puteri is located in an advanced township in Johor, namely Pasir Gudang in which the access to information and knowledge is easy thus provide a rich environment to students' learning in and outside of their formal schooling. The family background of the students is mostly from the profesional and entrepreneurial groups with an income of RM2500 and above thus the parents are able to provide adequate support for their children's learning.

\subsection{SMK Kinarut}

Students from SMK Kinarut scored between 1-6 marks in the pre-test results while in the post-test results they scored between 4-10 marks. (see Table 1). In addition, 100 per cent of the students showed an improvement from their pre to post-test results. ,

Table 5. Paired sample $\mathrm{t}$-test analysis for SMK Kinarut

\begin{tabular}{|c|c|c|c|c|c|c|}
\hline & \multicolumn{3}{|c|}{ Mean differences } & \multirow[t]{2}{*}{$\mathbf{t}$} & \multirow[t]{2}{*}{ df } & \multirow[t]{2}{*}{ Sig. (2-tail) } \\
\hline & $\mathbf{N}$ & \begin{tabular}{lr}
\multicolumn{1}{c}{ Mean } & Pre-test $\&$ \\
Standard & Deviation \\
(SD) &
\end{tabular} & $\begin{array}{l}\text { Mean Post-test \& } \\
\text { Standard Deviation } \\
\text { (SD) }\end{array}$ & & & \\
\hline Scores & 34 & $3.44(1.60)$ & $6.91(1.02)$ & -12.65 & 33 & .000 \\
\hline
\end{tabular}

As seen in Table 5, the mean score for pre-test is $3.44(\mathrm{SD}=1.60)$ and the mean score for post-test is 6.91 $(\mathrm{SD}=1.02)$. The difference in mean scores is 3.47 and it is found to be statistically significant at $0.05(\mathrm{p}=0.000)$. While the range of scores is wide for both pre and post-test that is 1-6 marks and 4-10 marks respectively. The mean value for both pre and post-test results is close to the mid value of the total mean, i.e. 5 . This suggests that students do improve from pre to post-test however it is still can be enhanced. Nevertheless the hands on activities might have some effect on this performance.

The students' performance after the workshop could be considered as satisfactory indicates that the learning environment in and outside of formal schooling is encouraging. SMK Kinarut is located in Kinarut which is situated at the fringe of the capital of Sabah, Kota Kinabalu. Students mostly come from a moderate family background where the family income is between RM1000-RM2500. Thus, providing basic needs of their children in gaining knowledge is assumed to be met by such family income bracket.

A comparison of performance according to gender Tables 6 and 7 present the mean score for the sample before and after using the learning module on Lichen and according to gender. Out of the 125 respondents, 48 of them are boys and another 77 of the sample are girls.

Table 6. Mean score according to gender for the total sample

\begin{tabular}{lcc}
\hline MEAN SCORE & GENDER & \\
\hline & Male & Female \\
Pre test & 3.19 & 3.93 \\
Post test & 7.12 & 6.45 \\
\hline
\end{tabular}


Table 7. Paired sampel t-test according to gender

\begin{tabular}{|c|c|c|c|c|c|c|}
\hline & \multicolumn{2}{|c|}{ Gender } & & \multirow[t]{2}{*}{$\mathrm{t}$} & \multirow[t]{2}{*}{$\mathrm{df}$} & \multirow{2}{*}{$\begin{array}{l}\text { Sig. } \\
\text { (2-tailed) }\end{array}$} \\
\hline & $\mathbf{N}$ & $\begin{array}{l}\text { Mean score Male } \\
\text { (SD) }\end{array}$ & $\begin{array}{l}\text { Mean Score } \\
\text { Female (SD)) }\end{array}$ & & & \\
\hline Pre test & 125 & $3.19(1.33)$ & $3.94(1.05)$ & -18.65 & 123 & .000 \\
\hline Post test & 125 & $7.12(1.24)$ & $6.45(1.22)$ & -11.66 & 123 & .000 \\
\hline
\end{tabular}

Both girls (mean=3.94) and boys (mean=3.19) obtained mean score below the mid value of the total score, i.e. 5 marks. However, the girls' mean score is higher than the boys indicating girls are more prepared and have the basic knowledge on the concept of Lichen. However, the boys did better in the post-test (mean=7.12) compared to the girls (mean=6.45), and the difference is found to be significant at $0.05(\mathrm{p}=0.000)$. At the same time, both girls and boys perform better compared to their performance in pre-test. One possible reason for this difference is that boys tend to perform well when involved in activities that involved students actively such as activities in the Lichen module.

\subsection{Students' Performance according to Questions}

Figure 1 displays the rate of change in students' performance for questions 1-9 based on the pre and post-test results. Question no. 10 was omitted from the analysis since the question was more on conceptual rather than on their performances. Students' performances were compared based on the type of schools.

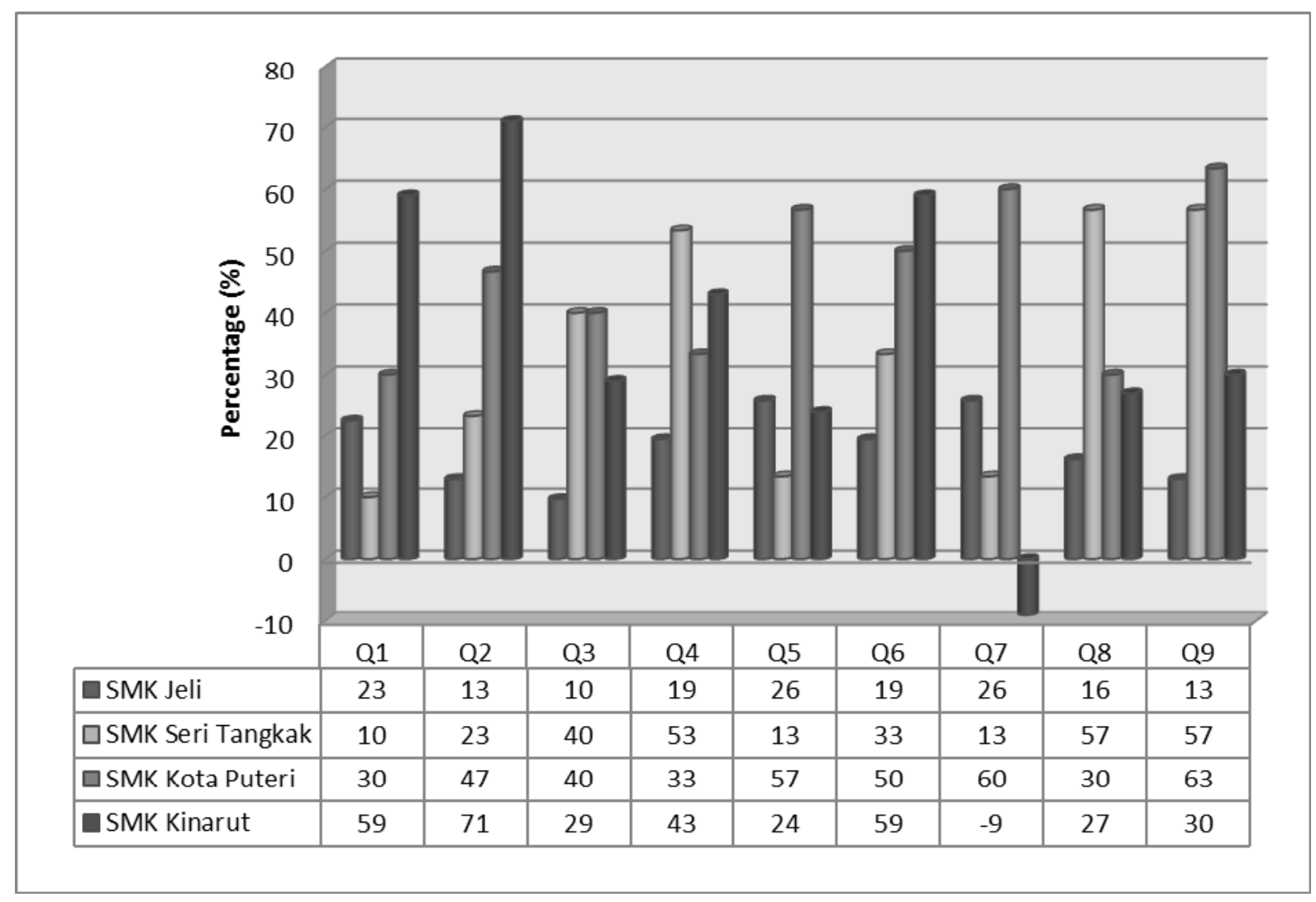

Figure 1. Student performances according to questions and schools

Overall, for each question, there is a positive change from pre to post-test result except for question no. 7 . Nine per cent of students from SMK Kinarut displayed a negative change from pre to post-test result. Question no. 7 is on the methods of identifying the index of air quality. This question requires mathematical competencies of the students. While, question no. 9 displays the highest rate of positive change in the students' performance. Question no. 9 relates to the function of Lichen. It appears that using environment as a learning space has a more 
positive effect on understanding the function of Lichen, in which Lichen is found in the environment itself thus students are able to relate to the concept easily . Nevertheless, it is encouraging to observe that almost 97 per cent of the students who attended the workshop showed a positive rate of change from the pre to post-test result.

\section{Conclusion}

This study has demonstrated that learning science and about the environment is not limited in the classroom but it can be effectively done outside the classroom. Learning activities that students are actively involved in the learning process have to some extend affect their performance in the understanding of Lichen and how this biological indicator can be used to determine the air quality. Thus, it is hope that through such an activity students is able to use their knowledge of the environment and science to manage their life better and is able to continue living in a healthy and less polluted environment. It is also acknowledge that other factors such as the students' family background and school location affect the students' performance other than the implementation of the module. Thus those sociological factors play an important role in reinforcing the students' learning, and should be considered in the continuous improvement of the learning and teaching module on Lichen.

\section{Acknowledgement}

This research was made possible through the support of Universiti Kebangsaan Malaysia and the research grant awarded KOMUNITI-2011-038 and Kementerian Pengajian Tinggi Malaysia (KPT) with the collaboration of Student Service Center (JPPEL) Universiti Kebangsaan Malaysia on the appointment of the Community Services Coordination 2012 (The Young Scientists Program).

\section{References}

Gigliotti, L. (1992). Environmental attitude: 20 years of change? The Journal of Environmental Education, 24, 15-26.

Hungerford, H. R., Volk, T. L., \& Ramsey, J. M. (1994). A Prototype Environmental Education Curriculum for The Middle School. USA: UNESCO.

Mageswary, K., Zurida, I., \& Norita, M. (2006). Knowledge, beliefs, desires and behavior of chemistry pre-service teachers towards the environment. Proceeding of The 2006 International Organization of Science and Technology Education. Penang, Malaysia. 487-494.

Mohd Wahid Samsudin, Laily Din, Zuriati Zakaria, Jalifah Latif, Tukimat Lihan, Abdul Aziz Jemain, \& Fazri Samsudin. (2011a). Measuring air quality using lichen mapping at Universiti Kebangsaan Malaysia (UKM) campus (Abstract). Kongres Pengajaran \& Pembelajaran UKM 2011. Penang, Malaysia.

Mohd Wahid Samsudin, Zuriati Zakaria, Rusli Daik, T. Subahan Mohd Merah, S. Intan Sharina S. Abdullah, \& Lilia Halim. (2011b). Lichens in the environment as a laboratory for environmental and science education (Abstract). Kongres Pengajaran \& Pembelajaran UKM 2011. Penang, Malaysia.

Nilsson, P. (2008). Teaching for Understanding: The complex nature of pedagogical content knowledge in pre-service education. International Journal of Science Education, 30(10), 1281-1299.

Norlila Talib. (2007). The implementation of Environmental Education among secondary schools in Seremban Master Dissertation: Universiti Kebangsaan Malaysia.

Sharifah Intan Sharina Syed Jamalulail. (2011). Pedagogical content knowledge of science teachers in teaching environmental education. Master Dissertation: Universiti Kebangsaan Malaysia. 